\title{
The strategic administration of the MSMEs
}

\section{La administración estratégica de las MSMEs}

CANTERA, Erika Emilia*†, LIMÓN-HERNÁNDEZ, Martha Eugenia and PECINA-RIVAS, Erika María

\section{Tecnológico Nacional de México / Tecnológico de Estudios Superiores de Cuautitlán Izcalli}

ID $1^{\text {st }}$ Author: Erika Emilia, Cantera / ORC ID: 0000-0002-9372-1450, CVU CONACYT ID: 647271

ID $1^{\text {st }}$ Coauthor: Martha Eugenia, Limón-Hernández / ORC ID 0000-0002-4800-0419, CVU CONACYT ID: 498939

ID $2^{\text {nd }}$ Coauthor: Erika María, Pecina-Rivas / ORC ID 0000-0001-6723-6139, CVU CONACYT 1027569

DOI: $10.35429 /$ JBS.2020.17.6.1.5

Received February 05, 2020; Accepted April 01, 2020

\begin{abstract}
The current market is aimed at companies being vulnerable to various external factors positively or negatively as economic, technological, political, environmental, demographic or social conditions and therefore must adapt and respond to the global environment. MSMEs face a greater number of problems, because they not only face the external factors mentioned above, but also their own limitations and weaknesses, of their company, so they must make a greater effort to compete against the Products or services that have a greater technological and marketing impact. This paper refers to a study of micro and small enterprises belonging to the State of Mexico, whose objective is to study their operational management and identify the main threats and weaknesses that they face in a competitive market.
\end{abstract}

Strategic Management, Micro and small businesses

\begin{abstract}
Resumen
El mercado actual está encaminado para que las empresas sean vulnerables a varios factores externos de forma positiva o negativa como son las condiciones económicas, tecnológicas, políticas, ambientales, demográficas o sociales por lo que debe adecuarse y responder al entorno global. Las MSMEs se enfrentan a un mayor número de problemas, debido a que no solo se enfrentan a los factores externos antes mencionados, sino a sus propias limitaciones y debilidades, de su empresa, por lo que deben hacer un mayor esfuerzo para competir frente a los productos o servicios competentes que tienen un mayor impacto tecnológico y mercadológico. El presente trabajo, hace referencia a un estudio de las micro y pequeñas empresas pertenecientes al Estado de México, cuyo objetivo es estudiar su gestión operativa e identificar los principales amenazas y debilidades a las que se enfrentan en un mercado competitivo.
\end{abstract}

Administración estratégica, Micro y pequeñas empresas

Citation: CANTERA, Erika Emilia, LIMÓN-HERNÁNDEZ, Martha Eugenia and PECINA-RIVAS, Erika María. The strategic administration of the MSMEs. Journal of Business and SMEs. 2020. 6-17: 1-5.

*Correspondence to the Author (Email: erika.cantera@tesci.edu.mx)

$\dagger$ Researcher contributing first author. 


\section{Introduction}

Micro, small and medium-sized companies are of great importance in the country's economy, not only because they provide the largest number of units, they also employ the largest number of people, however, they have various external problems to adapt to the such a changing and internal market due to its management of operating (Cantera 2019).

The present work shows the results of questions asked to micro-entrepreneurs and small companies about the management of operating their business, regarding their Planning and the areas of their personnel, marketing of their product or service and their finance. The years of operating with respect to the business range from 1 to 5 years in the market..

\section{Developing}

The strategic management process, dynamic in nature, is made up of the set of commitments, decisions and acts that the company needs to carry out to achieve strategic competitiveness and obtain above-average profits.

It is defined as the art and science of formulating, implementing and evaluating multidisciplinary decisions that allow a company to achieve its objectives. As this definition suggests, strategic management focuses on integrating management, marketing, finance and accounting, production and operations, research and development, and information systems, to achieve the success of an organization. (Barjas, F., 2011).

In the results of the 2014 Economic Census applied by INEGI, the private and parastatal sector companies considered for the purpose of the analysis add up to 4230745 , $98.6 \%$ focusing on the services, commerce and manufacturing sector; and according to the number of employees from 0 to 10 people, they represented two thousand thirteen $95.4 \%$ for the year, located in micro and small companies.

MSMEs in Mexico, as in developed countries, play an extremely important role in job creation and in the number of economic units. Therefore, influencing the growth of these companies implies affecting the overall behavior of the national economy.
The situation that is worrying is the figure for gross production. The INEGI data show that despite being the largest number of companies and generating almost three quarters of total employment, in production the MSMEs only generate together $35 \%$ of the total product in a grouped manner. Even if only micro companies are considered for analysis purposes, it is obtained that $95 \%$ of the existing companies generate just over $8 \%$ of the total national gross production, but create almost four out of every ten jobs (Hernández, 2009).

In the article called the management processes and the SMES problem, he points out that small and medium-sized enterprises (SMES) in Mexico are of great importance since they help the Mexican economy by employing almost $72 \%$ of the population and contributing with approximately 52\% of the Gross Domestic Product (GDP). Currently, in addition to contributing to economic growth, it also supports job creation and regional and local development. Despite being very important for the economy, SMEs do not have the necessary resources to fully develop, they are now facing a bigger problem, globalization, which is the large-scale process of information, technologies, cost reduction and transportation, ensuring that companies establish themselves in other countries while being even more competitive and that obstacles to international trade are removed (Palomo, 2005).

The generic strategies of any company must focus on one of the three most significant, such as: cost leadership, differentiation and targeting. So the strategic map to design for the specific sector of analysis should mainly point to one of the three strategies mentioned above. To follow a cost leadership strategy, technological improvements must be implemented that allow us to be competitive with high levels of quality, strategic integration with suppliers and customers, and risk reduction and cost distribution with the competition.

Therefore, the management model must monitor work activity on all fronts: coordinated work between the MSMEs in the cluster, with other companies in related clusters, government entities and end customers. (Porter. 1998). 


\section{Methodology to develop}

This work shows the second part of the study of twenty-five micro and small companies of different types, twelve manufacturing, three commercial and ten services, according to the size and number of employees twenty are micro-companies and five are small, $40 \%$ of them have been in the market for five years, $25 \%$ four years and the rest from one to three years; a questionnaire was applied to the owner or manager who knew the operation of the operational management, the assimilated companies are located in the municipality of Cuautitlán Izcalli and nearby and were chosen after reviewing that they would answer all the items and that they were in the micro range and small businesses.

The questionnaire used for the collection of information consists of twenty questions and five demographic information, which included closed-ended questions related to strategic planning as a primary part of the future of any organization, and three functional areas of the companies: Personnel Administration, Marketing Management and Financial Administration.

\section{Results}

In the diagnosis of the micro and small companies studied, in Table 1, it is observed that they do not have formal practices regarding Personnel Administration, they do not look for people outside the business, their recruitment is internal through relatives or acquaintances, therefore, neither do they use the various selection techniques (Cantera et.al., 2016), such as skills, knowledge or psychometric tests. Once working, the manager or owner performs performance evaluation through observation and supervision, there being other techniques to determine their performance, therefore, it is difficult for their employees to be replaced if they are poorly evaluated.

\section{Personal}

\begin{tabular}{|c|c|c|}
\hline $\begin{array}{l}\text { Elements that were } \\
\text { considered } \\
\text { Personnel } \\
\text { Administration }\end{array}$ & $\begin{array}{l}\% \text { of } \\
\text { companies } \\
\text { that do it }\end{array}$ & $\begin{array}{l}\% \text { of } \\
\text { companies } \\
\text { that do not } \\
\text { carry out }\end{array}$ \\
\hline Recruitment & $5 \%$ & $95 \%$ \\
\hline Selection & $12 \%$ & $88 \%$ \\
\hline Training & $76 \%$ & $24 \%$ \\
\hline Motivation & $80 \%$ & $20 \%$ \\
\hline $\begin{array}{l}\text { Performance } \\
\text { evaluation }\end{array}$ & $88 \%$ & $12 \%$ \\
\hline Feedback & $76 \%$ & $24 \%$ \\
\hline Total & $56.1 \%$ & $43.9 \%$ \\
\hline
\end{tabular}

Table 1 Result of Personnel Administration

Strategic Planning refers to the set of commitments, decisions and acts that every company needs to carry out to achieve competitiveness (Hitt, cited by Torres, 2014), in Table 2, it is observed that $57 \%$ of the companies surveyed, they do not carry out strategic planning, despite the fact that $82 \%$ take into account their vision of what they want to become, their decisions are few, or they only do it reactively, rather than proactively.

In another study on the administrative process of micro and small companies, they lead to the same result (Villalobos \& Trejo, 2016), a deficiency in the planning phase despite being essential for risk reduction and taking advantage of opportunities.

\section{Strategic planning}

\begin{tabular}{|c|c|c|}
\hline $\begin{array}{l}\text { Elements that } \\
\text { were considered } \\
\text { in Personnel } \\
\text { Administration }\end{array}$ & $\begin{array}{l}\% \text { of } \\
\text { companies that } \\
\text { do it }\end{array}$ & $\begin{array}{l}\% \\
\text { companies } \\
\text { that do not } \\
\text { carry out }\end{array}$ \\
\hline Vision & $82 \%$ & $18 \%$ \\
\hline Written goals & $53 \%$ & $47 \%$ \\
\hline $\begin{array}{l}\text { Written policies } \\
\text { and rules }\end{array}$ & $11 \%$ & $89 \%$ \\
\hline $\begin{array}{l}\text { Joint decision- } \\
\text { making }\end{array}$ & $26 \%$ & $74 \%$ \\
\hline Total & $43 \%$ & $57 \%$ \\
\hline
\end{tabular}

Table 2 Strategic Planning Result

Marketing (Kotler, 2012), tries to identify and satisfy human and social needs in a profitable way for the company, through communication, delivery and exchange towards consumers. 
In the result of the study, it is observed in Table 3, that on average $56.75 \%$ consider marketing management, know the needs of their clients and even offer promotions or discounts, however, they do not use advertising media, Despite the fact that advertising is the effective way to disseminate messages to create brand, product or service preference (Kotler, 2012), for example, large companies, despite being possessed in the market, always allocate a percentage to advertising, which which should take into account the MSMEs.

\section{Marketing Management}

\begin{tabular}{|l|r|r|}
\hline $\begin{array}{l}\text { Elements that were } \\
\text { considered in } \\
\text { Personnel } \\
\begin{array}{l}\text { Administration } \\
\text { companies }\end{array}\end{array}$ & $\begin{array}{l}\text { of } \\
\text { that do it }\end{array}$ & $\begin{array}{l}\text { of } \\
\text { companies } \\
\text { that do not } \\
\text { carry out }\end{array}$ \\
\hline $\begin{array}{l}\text { Customer needs } \\
\text { media advertising }\end{array}$ & $82 \%$ & $18 \%$ \\
\hline $\begin{array}{l}\text { Electronic } \\
\text { advertising media }\end{array}$ & $35 \%$ & $65 \%$ \\
\hline $\begin{array}{l}\text { Promotion } \\
\text { discounts }\end{array}$ & $45 \%$ & $55 \%$ \\
\hline Total & $65 \%$ & $35 \%$ \\
\hline
\end{tabular}

Table 3 Marketing Management Result

Finance is currently a fundamental part of companies and the proper use of resources, their forms of financing and good control of the accounting process. In Table 4 , it is observed that only $12 \%$ make use of financial credits, $53 \%$ have the capacity to cover working capital expenses and cover their needs for inputs, raw materials or labor.

\section{Financial administration}

\begin{tabular}{|c|c|c|}
\hline $\begin{array}{l}\text { Elements that were } \\
\text { considered } \\
\text { Personnel } \\
\text { Administration }\end{array}$ & $\begin{array}{l}\% \text { of } \\
\text { companies } \\
\text { that do it }\end{array}$ & $\begin{array}{l}\% \\
\text { companies } \\
\text { that do not } \\
\text { carry out }\end{array}$ \\
\hline Financial credit & $12 \%$ & $88 \%$ \\
\hline Working capital & $53 \%$ & $47 \%$ \\
\hline Information systems & $62 \%$ & $38 \%$ \\
\hline Total & $42.3 \%$ & $57.7 \%$ \\
\hline
\end{tabular}

Table 4 Financial Management Result
Of the people surveyed, their profile of each leader was also determined, where the male sex obtained $56 \%$ and $44 \%$ are women, and $45 \%$ of them have a bachelor's degree. $40 \%$ a profession and 15\% secondary; Regarding age, the percentage with the highest incidence is between 41 and 50 years with $50 \%$, between 31 and 40 years they represent $31 \%$ and between 21 and 30 years it was $6 \%$.

\section{Conclusions}

The MSMEs represent an important percentage for the contribution of the national economy and as personnel employers, even the micro companies with less than ten people for their operation, represents $95.4 \%$ according to the National Institute of Statistics and Geography (INEGI, 2014). However, various studies, including the present one, show the lack of knowledge and skills or the use of customs to adapt to the current market.

Even though a considerable percentage of owners or managers have a profession, the results show that, because they are family businesses and that the employees are familiar or well-known, they do not use tools and techniques typical of Personnel Administration, nor the use of advertising. as part of marketing. In addition, their lack of decision-making causes them to have working capital problems and to consider credits or external financing.

Currently various public or private organizations support the MSMEs sector for its growth and development; the federal or state governments through various instances offer advisory or economic support for their growth, the entrepreneurs themselves seek consultancies or information from secondary sources for the resolution of the problem and training. However, techniques or tools such as information systems must be adapted to the characteristics of a company with less than thirty workers, make a collaboration between the same micro and small companies, and create a competitive advantage over larger companies, as of any must align with the trends imposed by the management of the XXI century. 


\section{References}

A. F. B. Hernández y H. A. Campuzano. (2009). Impacto de la Apertura Comercial y la Inversión Extranjera Directa en el Crecimiento de las SMEs. Ubicado en: http://www.mundosigloxxi.ciecas.ipn.mx/pdf/v 02/07/09.pdf

Barajas, Fernando. (Octubre, 2011). Impacto de las TIC en las SMEs mexicanas. Ciencia y Desarrollo, $\mathrm{N}^{\circ} 4,11,12$.

Cantera, Erika Emilia, Martha Hernández Limón \& María Erika Pecina Rivas (2019). Operations management of the MSMEs. RINOE Journal Financial Economy. ubicado en: http://www.rinoe.org/spain/Journal_Financial_ Economy/vol3num4/Journal_Financial_Econo my_V3_N4_3.pdf

Cantera, Erika Emilia, María Gabriela Muñoz Guillen y Patricia Cortés Hernández. (2016). Reclutamiento y Selección un estudio en las MSMEs del Municipio de Cuautitlán Izcalli, Estado de México. Observatorio Economía Latinoamericana. Eumed.net. ubicado en: http://www.eumed.net/cursecon/ecolat/mx/2016 /seleccion.html

Instituto Nacional de Estadística y Geografía. (2014). Micro, pequeña, mediana y gran empresa, Estratificación de los establecimientos. Censos Económicos 2014. http://internet.contenidos.inegi.org.mx/contenid os/productos//prod_serv/contenidos/espanol/bvi negi/productos/nueva_estruc/702825077952.pd $\mathrm{f}$

Kotler, P.\& Keller, K. L. (2012). Dirección de Marketing (14th ed.). México: Pearson Educación de México S.A de C.V.

Mariño Becerra, Gladys Yaneth \& Inelia Medina Sandoval. (2009). La administración financiera: Una útopía en las microempresas. Universidad Libe Colombia. http://www.unilibre.edu.co/CriterioLibre/image s/revistas/11/CriterioLibre11art05.pdf

Porter, M. (1998). Cluster and the New Economics of Competition. Ed. Harvard Business School Press. Libro Clásico

Torres Hernández, Zacarias. (2014). Administración Estratégica. Grupo Editorial Patria.
Villalobos Valero Jessica \& Emma Yesmin Trejo Kuri. (2016). El proceso Administrativo en la MSMEs. Tlamali Sabiduría Volumen 7 número especial 1. Encuentro de Jóvenes en la investigación de Bachilerato-Conacyt. 